\title{
$S$-singulatives in Ket*
}

The paper focuses on an interesting aspect of synchronic and historical morphology of the Ket language and its implications for the reconstruction of Proto-Yeniseian. Based on relic evidence, it is suggested that the component -s' in some Ket nominal stems should be analyzed as a desemanticized singulative marker, possibly still productive at an earlier time stage; internal and external evidence for this hypothesis is presented and discussed.

Keywords: Yeniseian languages, Ket language, fossilized morphology, singulatives.

To the memory of Sergei Starostin

\section{Introduction}

An etymological comment to Yen. ${ }^{*} \jmath k s i(\sim x-)$ 'tree' (Ket ōks', pl. $a^{2} q$; Kott atče, atči, pl. ak, ax, $\bar{a} x$ ) in Sergei Starostin's Comparative Vocabulary of the Yeniseic Languages reads as follows:

The form of the plural in this case goes back undoubtedly to Proto-Yen. * $x a^{2} q$ 'trees, forest' (q.v.). If so, it can be assumed that Proto-Yen. * $x$ sks developed from the original compound ${ }^{*} x a^{2} q-s V$ or ${ }^{*} x a^{2} q-x u s a$, lit. 'tree single' (a similar compound being present e.g. in *de-s 'eye', etc.). (Starostin 1995: 198)

The idea of decomposing some Yeniseic stems with singling out the morpheme * $s(V)$ with singulative meaning can be found, explicitly or implicitly, also in several other entries of this vocabulary, see s.v. ${ }^{*} d e-s$ 'eye', * $p a$ (> Ket $h \overline{a s}$ ') 'time (= occurrence)', ' $\chi u$-sa 'one' (Starostin 1995: 220, 244, 306).

The analysis suggested by Starostin differs from the treatment of the pair $o^{\prime} k s^{\prime}-a^{2} q$ in many earlier (and later) publications. They are often mentioned as merely suppletive - presumably unconnected - stems, on a line with $k e^{2} t$ 'person, man' - $d e^{2} \eta$ 'men, people' (Kreinovich 1968: 82; Vall, Kanakin 1985: 13). T. I. Porotova also views them as suppletive, adding a comment according to which the last consonant in $o-q-s\left(=o^{*} k s^{\prime}\right)$ must be a verbal marker of state corresponding to German ist (sic! - “глагольный показатель состояния, соответствующий немецкому 'ist'”) which is absent in plural as long as it denotes a singular state (Porotova 1990: 48). ${ }^{1}$ In the publications by H. Werner one can find both a mention of supple-

* This paper must have been written in 2005 or 2006 and was intended to be published in a volume dedicated to the memory of Sergei Starostin that was being planned in the USA, but has never been completed. The paper was accessible on the internet as a pdf-file with some technical shortcomings - namely, most special symbols were missing. Here they were restored and checked against the published sources; also, a handful of missing references have been added. This publication is a part of the project on publishing the etymological legacy of Eugen Helimski (RFH project No 14-04-00496a). - Valentin Gusev.

${ }^{1}$ See fn. 4 on backgrounds of this peculiar comment. 
tivism (Werner 1997a: 68) and classifying $o^{\prime} k s^{\prime}-a^{2} q$ under a big group of words in Ket in which the opposition singular : plural is manifested through a consonant alternaion and/or an epenthesis (Werner 1995: 89-90). His comprehensive Yeniseic dictionary contains no statements concerning the kind of relationship between ${ }^{1} o^{\circ} k s^{\prime}$ and ${ }^{2} a^{2} q$ (and even no reference from the latter entry to the first one), see VWJS 1: 86, 2: 50.

It has been known since Castrén's times that the category of number in Yeniseic (both in Ket with Yug and in Kott) abounds in irregularities; using a plural suffix (- $\eta$ or $-n$, with phonetically and lexically determined distribution) is a typical, but by no means the only way of differentiating between singular and plural forms. I would dare to assert that the numerous treatments and materials published in the last decades, including a special monograph by Porotova (Porotova 1990), added a lot to listing such irregularities but, as long as explanations and attempts at formulating at least some rules are concerned, did not contribute much to the classical presentation by Castrén (1858: 16-25) and to solving the problems discussed by Kreinovich (1968: 79-83), Toporov \& Civjan (1968: 235-241). With its intriguing yarn of forms, the Yeniseic category of number challenges linguists with one of numerous riddles posed by these typologically unique languages.

Addressing only one aspect of this riddle, I am going to show in this paper:

- that one of the factors responsible for the complicated sets of number forms in Ket (and in Yeniseic in general) consists in superimposing and intermingling of two oppositions, singular vs. plural and general vs. singulative, the first one being inflectional and the second one - primarily at least - derivational;

- that, in accordance with the assumption made by Starostin, ${ }^{*}-s(V)$ (Ket mostly $\left.-s^{\prime}\right)$ can be viewed as a diachronically, and partly also synchronically, productive suffix of singulative forms.

Notes: (1) The structure of the Yeniseic languages makes the differentiation between morpheme borders and word borders, resp. between synthetic and analytic forms, between derivation and word compounding, between suffixes and final elements in compounds embarassing, and probably - diverting from the practical issue of orthography - not obligatory.

(2) Ket and other Yeniseic forms are quoted in this paper mainly (unless otherwise indicated) after Werner's VWJS, partly also from Porotova's SKS. The phonetic notations are therefore only partly unified (not more than in these sources). It is regretfully impossible to systematically differentiate between very phonetically exact transcriptions, characteristic of Werner's own records (these transcriptions usually contain the marking ${ }^{1-4}$ for prosodic types), and less reliable records which he quotes in VWJS along with his own, as well as between records in which differing graphic/transcriptional systems are used. Under these circumstances it is superfluous to comment on many minor details of phonetics which can result from dialectal or individual variation as well as from the peculiarities (and quality) of transcription.

\section{2. de's'singulatives in Ket}

The notion of singulatives is by no means new in Yeniseic linguistics. This term has been applied to a large group of compounds in Ket which include a noun (usually denoting substances, masses, foodstuffs, natural phenomena) as their first component and the word (suffix) de's' ('eye') as the second one, cf. e:l' 'berries' - e:l'des' '(a single) berry' (VWJS 1: 258 - ${ }^{3}{ }^{2}: l$ ', ${ }^{3}$ 'cl'des'), qo: 'hail' - qo:des' 'hailstone', etc., see Porotova 1990: 65-66. In her analysis Porotova stresses that (a) there are nouns which form both plural forms and singulatives, cf. han'a 
'sand' - hnn'ayan 'sands' - hundes' (VWJS 1: 338 - hín'aydis') 'sandstone, a grain of sand'; (b) singulatives can have plural forms of their own, cf. qo:des'an 'hailstones ( $\approx$ hail)' - it is reasonable to keep both these properties of de's'-singulatives in mind when dealing with presumably older s'-singulatives.

It can be added that in several cases Ket sources quote a de's'-singulative as "singular" and the form without this element as "plural”, cf. Toporov, Civjan 1968: 237 or the entry Pak. qońdes, qo:ńde:s', pl. qon 'бисерина, зрачок // bead, pupil (of the eye)' in SKS.

In the following the productive and transparent category of de's'singulatives is left aside. It can be thought, however, that it arose as a functional replacement of a similar category which, in the course of time, lost its productivity and transparency.

\section{Data on s-singulatives}

3.1. The Ket pair $o^{\prime} k s^{\prime}-a^{2} q$, or one of its members, has the following attested correspondences in other Yeniseic idioms: Yug (Sym Ket) ${ }^{1} o k s i$ and ${ }^{2} a^{2} \chi$ 'trees, forest, wood', Kott atći 'Baum', ачи 'дерево' (cf. also ачихах 'вершина', ачичан 'корень') and $\bar{a} x$ ( $a g, a k, a x)$ 'Bäume, Wald' with plural ägan (! - see below), ак 'дрова, лес', Arin отши 'дерево, лес', отшил 'дерево' (cf. also ошапок 'вершина') and оо 'дрова, лес', Pump. hóchon 'sylva, arbor' (cf. also chógon in chógon-dýpun 'folium'), see Castrén 1858; Helimski 1986; Starostin 1995: 198, 295; VWJS 1: 86, 2: 50 (for the sake of precision, data from older sources are quoted here with their original spellings and translations).

I believe that the reconstructions suggested by S. Starostin and Werner need both a phonetic and a semantic refinement. First, the proto-form for $a^{2} q$ (Starostin: ${ }^{*} x a^{2} q$, Werner: ${ }^{*} a^{2} q$ ) should not contain an internal glottal stop, the latter being a phonetic (or prosodic) segment automatically appearing in Ket and Yug monosyllables with primary consonantal Auslaut (see Helimski 2000). ${ }^{2}$ Second, the basic meaning of this word should be preferably reconstructed not as plural 'trees' (Starostin: 'деревья', Werner: 'Bäume' > 'Wald', 'Holz'), but rather as general (substance name) 'wood, chopwood, firewood'. ${ }^{3}$ This is confirmed also by numerous verbal derivatives such as Yug áxat 'Holz besorgen, Vorräte an Holz anlegen', Ket aq...vet 'Holz haben', áRasej 'Holzvorräte anlegen', Kott agat âqๆ (Nom. act. agat) 'hauen'.

3.2. The element $-s^{\prime}$ is present in the singular form and absent from the plural form not only in the pair $\bar{o} s^{\prime}-a^{2} q$, but also in at least three or four further stems, all belonging to archaic strata of the Ket (Yeniseic) vocabulary. These are as follows:

- Ket ${ }^{2} s^{\prime} \varepsilon^{2} s^{\prime}$, pl. ${ }^{1} s^{\prime} e^{\prime} j$ 'лиственница // larch', Yug ${ }^{2} s \varepsilon^{2} s$, pl. ${ }^{1} \operatorname{sej}$ (the SKS quotes also Yug plural forms with the plural marker $-\eta$ added to either $s \varepsilon^{2} s$ or sej: Sym šeei Yeniseic counterparts can contain different suffixal elements: Kott šêt, pl. šat, Arin čit, Pump. tag. Cf. also a derivative or compound in which a CV-variant of this stem seems

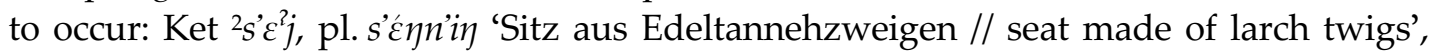
Yug ${ }^{2} S \varepsilon^{3} j$, pl. sén $n^{\prime} i \eta$ (the suffixal or second part is $-j$, pl. $(-\eta-) n^{3} i \eta<(-\eta-) j i \eta$, as in ${ }^{2} u^{3} j$, pl.

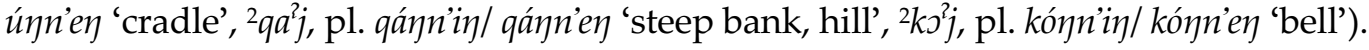

${ }^{2}$ Also in recent Russian loanwords: Ket $s^{\prime} a^{2} j$ 'tea', $l$ ' $\varepsilon^{2} s$ 'forest', $h \partial^{2} p$ 'priest', $m e^{2} t$ 'copper', me $t$ 'honey' (< Russ. чай, лес, поп, медь, миё).

${ }^{3}$ Note the misunderstandings which arise from the somewhat inadequate choice of translation equivalents. For example, it is customary to translate Ru. дерево simply as 'tree', though in numerous contexts - statistically, perhaps, even more frequent - it means 'wood' and denotes material rather than a natural object. 


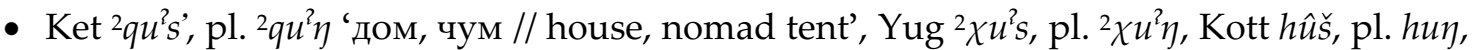
Arin -k'us,-kus, Pump. -kut (hukùt), see WVJS 2: 140 with the comment: "Nach der Pluralbilding läßt sich ein altes Kompositum vermuten" (NB: Pump. $t$ is the regular continuation of Yen. ${ }^{*} s>$ Ket $s$ ').

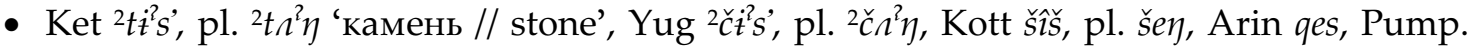
kit (Werner in VWJS 2: 85 tends to view the forms in Arin and Pump., with pl. not attested, as unrelated to $\left.{ }^{2} t i^{2} s^{\prime}\right)$.

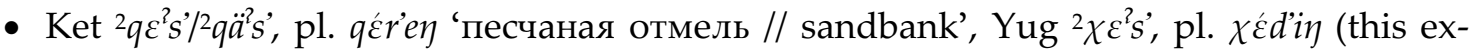
ample belongs together with the rest of this group if ${ }^{2} q \varepsilon^{2} s^{\prime} /{ }^{2} q \ddot{a}^{2} s^{\prime}<{ }^{2} q \varepsilon^{2} d s^{\prime} /{ }^{2} q \ddot{a}^{2} d s^{\prime}$, which probably cannot be proven).

Besides, the same relationship between number forms is attested in several dozen compound words with one of the above stems as the second component: (SKS) Kel. il'oks', pl. il'aq

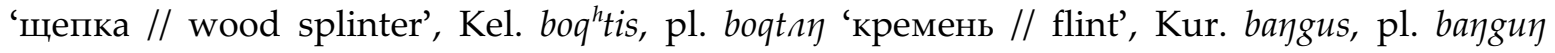
'землянка // dugout', etc. etc.

3.3. It can be argued that in the above cases the "pure" stem (without *-s or the plural marker $\left.{ }^{*}-\eta\right)$ denotes substances: wood $\left(a^{2} q\right)$, larch wood $\left(s^{\prime} e^{\prime}(j)\right)$, stone $(t i-)$, possibly also river sand $(q \varepsilon(d)-)$, while the "singular" form denotes a unit of this substance (tree, larch tree, rock, sandbank), and the "plural" form with a formal plural marker $-\eta$ several or many such units (stones = rocks, sandbanks). A similar relationship can be assumed also for $q u-$, possibly 'home, dwelling place', its single unit being a house, a tent. This semantic analysis is further supported by the fact that the unmarked "plural" forms can build plural forms of their own: Kott âgan ('forests'), Yug (Sym) šeein (it can be supposed - but not checked any more, since the dialect is by now extinct - that this plural form actually meant 'larch forests', as distinct from ${ }^{1}$ sej 'larches, larch forest').

By the way, the above observations discard the popular but superficial and groundless comparisons of Yeniseic words for 'house' and for 'stone' with German * $x \bar{u} s-(>$ house) and with Turkic * $t \bar{a} \breve{s}$, correspondingly.

3.4. The following Ket and Yug examples serve as further attestations of the element $-s\left(-s^{\prime}\right)$ and its function:

- Ket ${ }^{1} o^{*} k$, pl. óks'in (Yug ${ }^{1} o k$, pl. óksin) 'sterlet'. The unusual plural marking (-s’in instead of $-n$ ) finds a reasonable explanation if we assume that ${ }^{1} \bar{o} k$ is a general noun denoting sterlet as a fish species, its singulative (which is even attested in SKS - not in VWJS as Kel. oks) denotes a sterlet as a single specimen belonging to this species, and óksin is the plural form to this singulative.

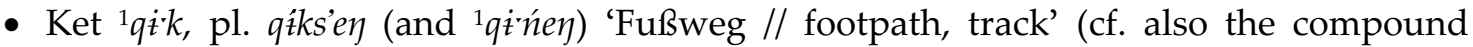

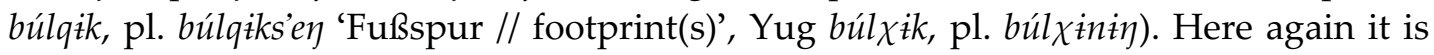
possible, hypothetically expanding the dictionary data, to assume that the form ${ }^{1} q \dot{i} k$ denotes a footpath/track as a sequence of footprints, its non-attested singulative ' $q i^{\prime} k s^{\prime}-$ a single footprint, and among the two plural forms qúks'e $\eta$ refers to a plurality of footprints (left e.g. by the same animal) and to a plurality of footpaths/tracks (left by several animals).

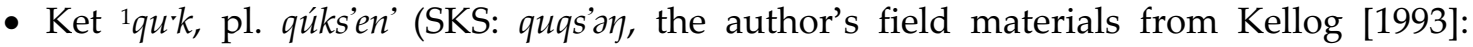

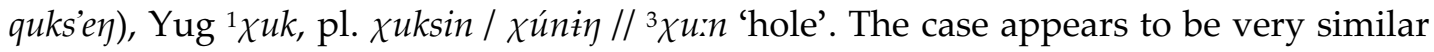
to the previous one, with some kind of - at least original - differentiation between and a hole/perforation in general and a single aperture. 
- Ket Kel. t'its' 'one generation', a derivative from Pak. tit $^{2}$ 'root' (SKS: 241).

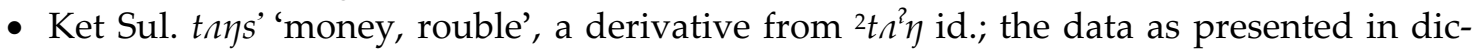
tionaries permit to assume that the meaning 'money' was primarily associated with the form ${ }^{2} t n^{2} y$, and the meaning 'rouble' (= 'a unit of money') with its s'-derivative (and it cannot even be excluded that this distribution is preserved, at least in dialects). On the other hand, ${ }^{2} t \Omega^{2} \eta$ must be, according to VWJS, etymologically identical with ${ }^{2} t \iota^{2} \eta$ 'stones' (see above): this suggests a scenario of formal and semantic differentiation between the archaic s'-singulative ' $t t^{2} s$ ' and the innovative $t \wedge \eta s^{\prime}$ (in which the function of the plural marker $-\eta$ is not "recognized").

- Ket ujs', újis' 'birch-bark laid under a baby', a derivative from ${ }^{2} u^{2} j$ 'cradle' (with presumable basic semantics 'a piece of cradle').

- Ket ' ${ }^{2}$ 'l's'/ul's', pl. úl's'en 'a big water basin (sea, long and wide river, the Yenisei)', a derivative from ${ }^{1} \mathcal{u} l$ ' 'water' (with presumable basic semantic 'a unit of water, water as a single whole').

\section{Discussion}

As is clear from above, it can be assumed that a number of nouns in Ket - first of all, words of general meaning (denoting substances, masses, groups) - must have been able to participate in a binary opposition, functioning both as general nouns (with the ability to form singulatives) and as singular nouns (with the ability to form plurals). Since several such nouns demonstrate the same property in Kott (or have exact correspondences of their s-singulatives in other, poorly attested, Yeniseic languages), this duality must have existed in Proto-Yeniseic.

Further development led in some cases to the reinterpretation of former singulatives as singular forms opposed to plural forms (especially if the shorter stem with general meaning was not preserved); in many other cases s-singulatives were perhaps lost or ousted by de's'-singulatives, so that the abovementioned examples are only scanty relics from the past. Still, it is hardly realistic to believe that the opposition "general : singulative" was ever as developed as to be comparable with the opposition "singular : plural" and to be an inflectional category rather than a productive derivational model. In any case, this development contributed to the formation of the present situation in Ket: "In gewissen Fällen ist die Pluralbildung immer noch ein Grenzfall zwischen Morphologie und Wortbildung” (Werner 1997b: 102).

The (historical) morphological analysis of number forms suggested in this paper stands relatively close to the one by Kreinovich (1968: 81-82), who saw in the pairs ${ }^{2} q u^{2} s^{\prime}-{ }^{2} q u^{2} \eta$, ${ }^{2} t t^{2} s^{\prime}-{ }^{2} t n^{2} \eta,{ }^{2} s^{\prime} \varepsilon^{2}{ }^{\prime}-{ }^{1} s^{\prime} e^{\prime} j$ the opposition of a singular suffix $-s^{\prime}$ vs. plural suffixes $-\eta$ and $-j$. Werner criticized Kreinovich's approach as unacceptable; this was made on several occasions - and with varying argumentation. One of his alternative versions says that -s' has nothing to do with the category of number: it belongs to the original root, and the consonant alternation finds its explanation in historical derivation and historical phonetics (Werner 1995: 87). However, there are examples indicating that the stem-final consonant $-s^{\prime}$ can be

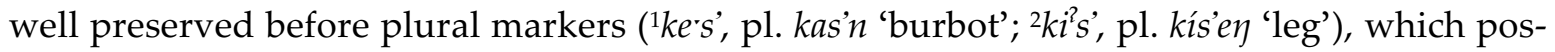
sibly led him to another explanation which, in my opinion, does not differ much from Kreinovich's approach:

In der Tat har man es in solchen Fällen in der Regel mit historischen Komposita zu tun, bei denen sich in Plural nur die Pluralform des ersten Kompositionsgliedes bewahrt hat; vom zweiten Kompositionsglied ist in der Singularform nur ein konsonantischer Rest übrig geblieben, der den Eindruck eines Reliktelements 
macht, welches E. A. Krejnovič als Marker des Singulars deutete. [...] Wörter mit dem Reliktelement -s (jug. -s/-̌̌) in der Singularform. (Werner 1998: 51, 52; similarly: Werner 1997b: 99)

Indeed, even the fact that the $s$ of the singulatives is in some examples attested as part of the stem in all Yeniseic languages (e.g. in Ket ${ }^{2} q u{ }^{2} s^{\prime}$, Yug ${ }^{2} \chi u^{2} s$, Kott hî̌s, Arin -k'us, Pump. -kut 'house') does not yet prove that it was always a suffix and not an independent word. It was already mentioned above that the structure (and history) of Ket makes the differentiation between derivation and word compounding - and even more, between "synthetic" and "analytic" forms in inflection - often problematic, and, in any case, hardly productive. The following pair of examples illustrates this thesis, but can possibly also shed some light on the connections - if not on the origin - of s-singulatives:

(a) Ket Kur. ${ }^{3} q \varepsilon: \gamma e t$, pl. qé tive function)' (pl. ${ }^{4} q \ddot{a} \eta$ ) and ${ }^{2} k \varepsilon^{2} t$ 'human being, man' (suppletive pl. ${ }^{2} d \varepsilon^{2} \eta$ 'people')

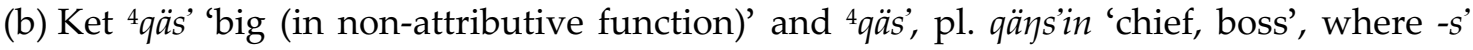
(pl. -s'in), usually treated by Werner (1998: 39) and other representatives of the Tomsk school as the so-called "predicative suffix", is added to ${ }^{4} q \ddot{a}$ instead of ${ }^{2} k \varepsilon^{2} t$.

Note that in (b), as well as in (a), the plural formes are double marked - the first adjectival component is in both cases supplied with the plural suffix $-\eta$. This means that, historically at least, "qüs' must also be viewed as a compound word.

The label "predicative suffix", introduced by A. P. Dulzon (1968) for the element $-s$ ' in non-attributive forms of adjectives, numerals, participles etc. which play an extremely important role in Ket grammar (as well as its counterpart -še/-ši, pl. -šin in the grammar of Kott), is misleading. The predicative function is only one (maybe the most important or the most frequent) function of the forms with this suffix, which occur, however, whenever an adjective etc. is used independently, without belonging to an attributive syntagm ${ }^{4}$. This accounts also for the fact that substantivized adjectives (like ${ }^{4} q u ̈ s$ ' 'chief, boss') and participles are systematically marked with this suffix.

Can it be that the suffix of non-attributive forms $-s$ ' and the singulative suffix $-s$ ' are of the same origin? I am not going to immerse here into details of this issue, but already the postpositive use of one in English with nonattributive/substantivized adjectives and participles ( $a$ / the big one, a / the standing one) makes such a historical connection extremely probable.

\section{Abbreviations}

Local varieties of Ket: Kel. - Kellog, Kur. - Kurejka, Pak. - Pakuliha, Sul. - Sulomaj.

\section{References}

Castrén, M. A. 1858. Versuch einer jenissei-ostjakischen und kottischen Sprachlehre. Hrsg. von A. Schiefner. St. Petersburg. Dulzon, A.P. 1968. Ketskiy yazyk. Tomsk: Izd-vo Tomskogo un-ta.

Helimski, E.A. 1986. Arkhivnye materialy XVIII veka po eniseyskim yazykam. In: Paleoaziatskiy sbornik. Leningrad: Nauka: 179-212.

Helimski, E.A. 2000. Glottalizaciya v yazykakh sredney Sibiri. In: Evraziyskoe prostranstvo: Zvuk i slovo. Mezhdunarodnaya konferenciya 3-6 sentyabrya 2000: Tezisy i materialy. Moscow: 17-18.

4 Too literal interpretation of the label "predicative suffix", plus the idea about the verbal nature of predicativity, were, as it seems, responsible for the strange analysis of the word $o^{*} k s^{\prime}$ suggested by Porotova (see Introduction). 
Kreinovich, E.A. 1968. Sposoby deystviya v glagole ketskogo yazyka. In: Vyach. Vs. Ivanov, V. N. Toporov, B. A. Uspenskiy (eds.). Ketskiy sbornik: Lingvistika. Moscow: Gl. red. vost. lit.: 75-138.

Porotova, T.I. 1990. Kategoriya mnozhestvennosti v eniseyskikh yazykakh. Tomsk: Izd-vo Tomskogo un-ta.

SKS = Porotova, T.I. 2002. Slovar' govornykh form ketskikh suschestvitel'nykh (s formami mnozhestvennogo chisla). Tomsk: TGPU.

Starostin, S.A. 1995. Sravnitel'nyy slovar' eniseyskikh yazykov. In: S. A. Starostin (ed.). Ketskiy sbornik: Lingvistika. Moscow: Yazyki russkoy kul'tury: 176-315.

Toporov, V.N., T.V. Civjan. 1968. Ob izuchenii imeni v ketskom (Nekotorye rezul'taty i perspektivy). In: Vyach. Vs. Ivanov, V. N. Toporov, B. A. Uspenskiy (eds.). Ketskiy sbornik: Lingvistika. Moscow: Gl. red. vost. lit.: $229-246$.

Vall, M.N., I.F. Kanakin. 1985. Kategorii imeni v ketskom yazyke. Novosibirsk: Nauka.

VWJS = Werner, Heinrich. 2002. Vergleichendes Wörterbuch der Jenissej-Sprachen. Bd. 1-3. Wiesbaden: Harrassowitz.

Werner, Heinrich. 1995. Zur Typologie der Jenissej-Sprachen. (Veröffentlichungen der Societas Uralo-Altaica, Bd. 45).

Wiesbaden: Harrassowitz.

Werner, Heinrich. 1997a. Das Jugische (Sym-Ketische). (Veröffentlichungen der Societas Uralo-Altaica, Bd. 50). Wiesbaden: Harrassowitz.

Werner, Heinrich. 1997b. Die ketische Sprache. (Tunguso-Sibirica, Bd. 3). Wiesbaden: Harrassowitz.

Werner, Heinrich. 1998. Probleme der Wortbildung in den Jenissej-Sprachen. (Lincom Studies in Asian Linguistics 25). München / Newcastle: Lincom Europa.

\section{Е. А. Хелимский. Сингулятивы на -s в кетском языке.}

Статья посвящена любопытному аспекту синхронной и исторической морфологии кетского языка, имеющему важное значение для праенисейской реконструкции. Основываясь на парадигматических характеристиках ряда архаичных форм, автор предполагает, что элемент -s', зафиксированный в некотором количестве кетских именных основ, следует анализировать как десемантизированный показатель сингулятива, по-видимому, обладавший продуктивностью на более ранних этапах развития кетского языка. В статье приводятся и подробно обсуждаются внутренние и внешние данные, так или иначе подтверждающие эту гипотезу.

Ключевые слова: Енисейские языки, кетский язык, застывшая морфология, сингулятив. 
